\title{
Paleomagnetic data from the Trans-Mexican Volcanic Belt: implications for tectonics and volcanic stratigraphy
}

\author{
Luis M. Alva-Valdivia ${ }^{1}$, Avto Goguitchaichvilii ${ }^{1}$, Luca Ferrari ${ }^{2}$, Jose Rosas-Elguera ${ }^{3}$, \\ Jaime Urrutia-Fucugauchi ${ }^{1}$, and Jose J. Zamorano-Orozco ${ }^{4}$ \\ ${ }^{1}$ Instituto de Geofísica, Universidad Nacional Autonoma de México, Laboratorio de \\ Paleomagnetismo y Geofísica Nuclear, Ciudad Universitaria, 04510 México D.F., México \\ ${ }^{2}$ Instituto de Geología, Universidad Nacional Autonoma de México, Apdo. \\ Postal 70-296, Ciudad Universitaria, 04510 México D.F., México \\ ${ }^{3}$ Centro de Ciencias de la Tierra, Universidad de Guadalajara, Calzada Olímpica \\ y Blvd. Marcelino Garcia Barragan, 44840 Guadalajara, Jalisco, México \\ ${ }^{4}$ Instituto de Geografía, Universidad Nacional Autonoma de México, Ciudad Universitaria, 04510 México D.F., México
}

(Received November 15, 1999; Revised June 5, 2000; Accepted June 9, 2000)

\begin{abstract}
We report a paleomagnetic and rock-magnetic study of Miocene volcanic rocks from the Trans-Mexican Volcanic Belt. A total of 32 sites (238 oriented samples) were collected from three localities: Queretaro, Guadalajara and Los Altos de Jalisco basaltic plateaux, which span from 11 to $7.5 \mathrm{Ma}$. Several rock-magnetic experiments were carried out in order to identify the magnetic carriers and to obtain information about their paleomagnetic stability. Microscopic observation of polished sections shows that the main magnetic mineral is Ti-poor titanomagnetite associated with exsolved ilmenite. Continuous susceptibility measurements with temperature yield in most cases reasonably reversible curves with Curie points close to that of magnetite. Judging from the ratios of hysteresis parameters, it seems that all samples fall in the pseudo-single domain (PSD) grain size region, probably indicating a mixture of multidomain (MD) and a significant amount of single domain (SD) grains. Based on our paleomagnetic and available radiometric data, it seems that the volcanic units have been emplaced during a relatively short time span of 1 to $2 \mathrm{My}$ at each locality. The mean paleomagnetic directions obtained from each locality differ significantly from that expected for the Middle Miocene. The mean paleomagnetic direction calculated from 28 sites discarding those of intermediate polarity is $I=32.46^{\circ}, D=341.2^{\circ}, k=7.2$ and $\alpha_{95}=11.6^{\circ}$. Comparison with the expected direction indicates some $20^{\circ}$ anticlockwise tectonic rotations for the studied area, in accordance with the proposed left-lateral transtensional tectonic regime already proposed for this period.
\end{abstract}

\section{Introduction}

The Trans-Mexican Volcanic Belt (TMVB), one of the largest continental volcanic arcs built on the North America plate, spans about $1000 \mathrm{~km}$ and crosses central Mexico from the Pacific to the Atlantic coast (Fig. 1). Subduction-related volcanism in Mexico resumed in the Eocene after Laramide deformation and formed the Sierra Madre Occidental silicic volcanic province (Fig. 1). During early to middle Miocene time, the volcanic arc rotated counterclockwise and, in the late Miocene, began to form the TMVB as a result of subduction of the Cocos and Rivera plates (Ferrari et al., 1999). The initial stage of the TMVB is marked by widespread basaltic volcanism, emplaced from the Pacific coast to the longitude of Mexico City, to the north of the modern volcanic arc (Fig. 1). This volcanism is characterized by plateau-like structures resulting from the coalescence of shield volcanoes and fissure lava flows, which have an estimated aggregate volume ranging between 3200 and $6800 \mathrm{~km}^{3}$ (Ferrari et al., 2000). Geologic and stratigraphic studies have shown that

Copy right(c) The Society of Geomagnetism and Earth, Planetary and Space Sciences (SGEPSS); The Seismological Society of Japan; The Volcanological Society of Japan; The Geodetic Society of Japan; The Japanese Society for Planetary Sciences. these basaltic lavas were emplaced in a period between about 11 and $8 \mathrm{Ma}$ (Ferrari et al., 1994a and 2000; Moore et al., 1994; Righter et al., 1995), which is also concurrent with the initial opening of the Gulf of California.

Several authors have suggested that during this period the TMVB, to the west of Guadalajara, experienced left-lateral transtensional tectonic deformation (Pasquaré et al., 1988; Garduño et al., 1993; Ferrari et al., 1994b and 2000; UrrutiaFugugauchi and Rosas-Elguera, 1994). However, due to the poor behavior of basaltic rock for recording slickensides on fault planes, left-lateral oblique faulting has been directly observed at only a few sites. On the other hand, their wellestablished stratigraphic position and the easy access of these basalts makes them a good target for paleomagnetic studies, with the purpose of determining to what extent this succession has been affected by tectonic rotation about a vertical axis. In this paper we present the results of a regional paleomagnetic study of the basaltic sequences, which also provides better constraints on the age of the rocks.

\section{Geologic Setting and Sampling}

We carried out systematic sampling at sites located in upper Miocene basaltic lava flows in four areas in the states of 


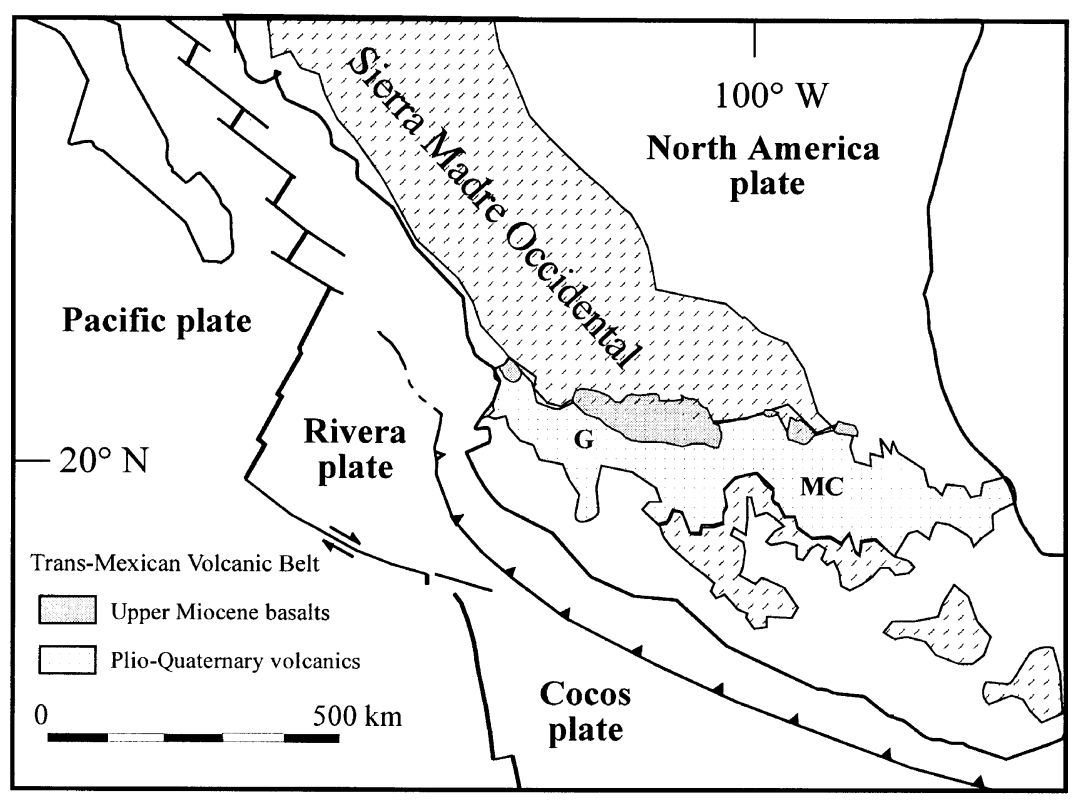

Fig. 1. Plate tectonic setting of central Mexico, showing the Cenozoic volcanic provinces and outcrops of upper Miocene mafic lavas. $\mathrm{G}=\mathrm{Guadalajara}$ $\mathrm{MC}=$ Mexico City.

Jalisco, Guanajuato, Queretaro, and Hidalgo (Figs. 1, 2, 3, 4). We focussed on sites where an isotopic age was available (Table 3) or that might be unambiguously correlated with dated sites.

The largest exposure of the upper Miocene basalts is along the Rio Grande de Santiago river canyon, north of Guadalajara (Figs. 2 and 3) where it has been informally named the San Cristobal basalt by Moore et al. (1994). The exposed volcanic succession is over $700 \mathrm{~m}$ thick and filled a pre-existing depression cut into lower Miocene ash-flow tuffs belonging to the Sierra Madre Occidental silicic volcanic province. We sampled this succession along two transects running along both riverbanks. The first one crosses the succession in a north-south direction at about $35 \mathrm{~km}$ north of Guadalajara (Fig. 2). Site BGC is located in an eroded basaltic shield volcano, dated at $11 \mathrm{Ma}$ (Moore et al., 1994), and represents the oldest rock of the succession. Two sites located to the south (AM) were later dated as early Miocene (Ferrari, unpublished data) and were therefore discarded from our paleomagnetic analysis. The rest of the sites (BM, and SCB series) are located at different elevations in the river canyon; where the succession was dated ca. $10 \mathrm{Ma}$ (Damon et al., 1979; Moore et al., 1994; figure 2). The second transect is located immediately east of Guadalajara, about $20 \mathrm{~km}$ south of the site of a previous paleomagnetic and geochronologic study by Watkins et al. (1971). Rocks sampled are not dated at this location but can be correlated with those dated by these authors between 9.5 and 9.0 Ma (Table 3).

East of Guadalajara, in the Los Altos de Jalisco region, the basalts exposed in the Rio Grande de Santiago river form a $130 \mathrm{~km}$ long, $60 \mathrm{~km}$ wide plateau, with a mean elevation of $1900 \mathrm{~m}$. In the Rio Verde valley, $25 \mathrm{~km}$ northwest of Tepatitlán (Fig. 3) the basalts are about $220 \mathrm{~m}$ thick and are affected by a left-lateral transtensional fault system running from Ixtlahuacán to San Miguel el Alto in a ENE-WSW direction (Ferrari et al., 2000, see also Fig. 3). The southern part of the Los Altos de Jalisco plateau is disrupted by an extensional fault system, which runs from Ocotlán to Cuerámaro (Fig. 3) and shows a left-lateral component of motion. In this area the basalts crop out in tilted blocks partly covered by younger volcanic rocks (Rosas-Elguera and Urrutia-Fucugauchi, 1998). We sampled several blocks disrupted by transtensional fault system (LC, LR, AC, CM, LP). Another three sites were sampled to the north, inside a less disturbed plateau (SJG, AR, CP) (Fig. 3). The available dates indicate that at all these sites the basalts were emplaced between $10.2 \pm 0.3$ and $8.7 \pm 1.0 \mathrm{Ma}$ (Nieto-Obregon et al., 1981; Nixon et al., 1987; Rosas-Elguera et al.,1989; RosasElguera and Urrutia-Fucugauchi, 1998).

East of Penjamo (Fig. 3), about $10 \mathrm{~km}$ north of Salamanca, upper Miocene basalts crop out as a tabular succession north of the Bajio fault (Nieto-Samaniego et al., 1999, figure 4). They range between 100 and $200 \mathrm{~m}$ in thickness, and overlie lower Miocene ash flows and Oligocene rhyolitic lava domes (Fig. 4). Other outcrops of mafic lava flows emerge from the alluvial filling of the Bajio depression are found north of Celaya (Fig. 4). The lavas of Salamanca and Celaya yield dates ranging between 9.5 and $10.5 \mathrm{Ma}$ (Hasenaka et al., 1994; Cerca-Martínez, 1998), suggesting that they represent fragments of a unique tabular volcanic structure. We sampled the site dated as 10.2 \pm 0.1 Ma by Hasenaka et al. (1994) (site $\mathrm{TH}$ ), which represents one of the youngest lava flows in the succession.

The most widespread outcrops of upper Miocene lavas are around the city of Queretaro (Fig. 4), where several isolated tabular volcanic structures likely represent remnants of an old plateau-like structure at a mean elevation of $1950 \mathrm{~m}$ (Fig. 4). The lava flows cap a fluvio-lacustrine succession and exhibit a total thickness of about $80 \mathrm{~m}$. Site AE is located in one of the uppermost lava flows exposed near the Queretaro airport, 


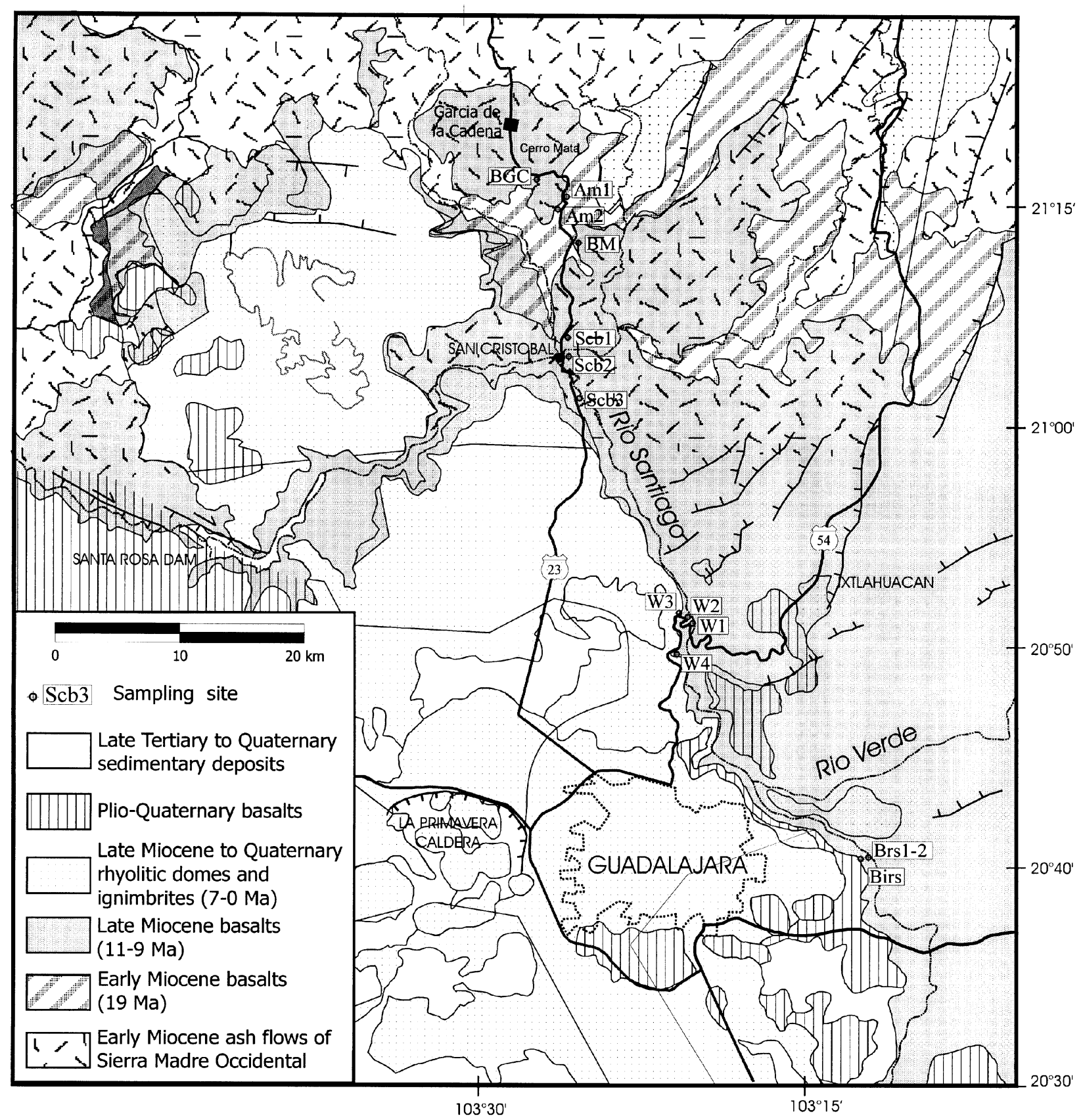

Fig. 2. Geologic map of the Rio Grande de Santiago and Guadalajara region with locations of sampling sites. Sites marked W1 to W4 are from Watkins et al. (1971).

having date of $8.1 \pm 0.8 \mathrm{Ma}$ (Pasquarè et al., 1991). Site VC was in a basaltic andesite from the bottom of the succession, with an age of 9.6 $\pm 1.0 \mathrm{Ma}$ (Murillo-Muñeton and TorresVargas, 1987). The other sites in the Queretaro area are in lava flows inferred to be bracketed between these dates (CA, LSE, LNE), except site CI, located in the Cerro Cimatario shield volcano, that caps the tabular basaltic succession and could be younger than the flows sampled at the Queretaro airport.

The easternmost exposure of upper Miocene basalts is in the state of Hidalgo around the Pathe geothermal area, $\sim 50 \mathrm{~km}$ east of Queretaro City (Fig. 4). The Pathé succession is defined by 80 to $300 \mathrm{~m}$ of sub-horizontal lava flows, in- terbedded with several spatter and scoria cones, which partly fed the basaltic succession. One of the uppermost lava flows was dated by Suter et al. (1995) at $7.7 \pm 0.1 \mathrm{Ma}$, using ${ }^{40} \mathrm{Ar} /{ }^{39} \mathrm{Ar}$ systematics. We sampled two flows at the base of the succession in the northwestern part of the lava field, which were dated by Jacobo-Albarrán (1986) at $9.3 \pm 0.5 \mathrm{Ma}$ (Fig. 4).

In total, 238 oriented samples belonging to 32 flows were collected. Commonly, the outcrops extend laterally over a few tens of meters and in these cases we drilled typically 8-10 cores per flow. The samples were distributed throughout each flow both horizontally and vertically in order to minimize effects of block tilting and lightning. In general, 


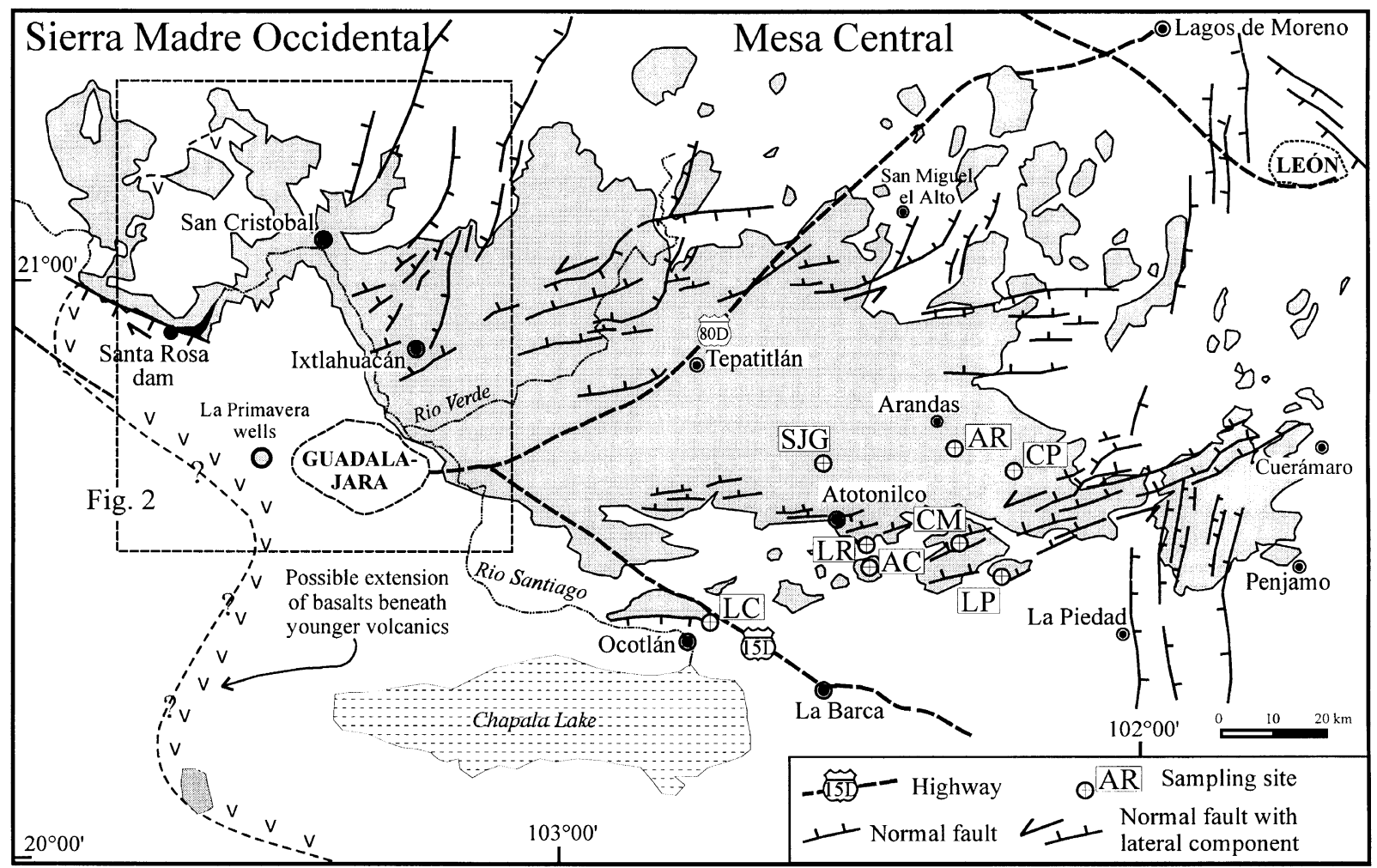

Fig. 3. Simplified geologic map of upper Miocene mafic lavas (in gray) and main fault systems of the Los Altos de Jalisco region (from Ferrari et al., 2000) with location of studied sites. The area covered by Fig. 2 is also indicated.

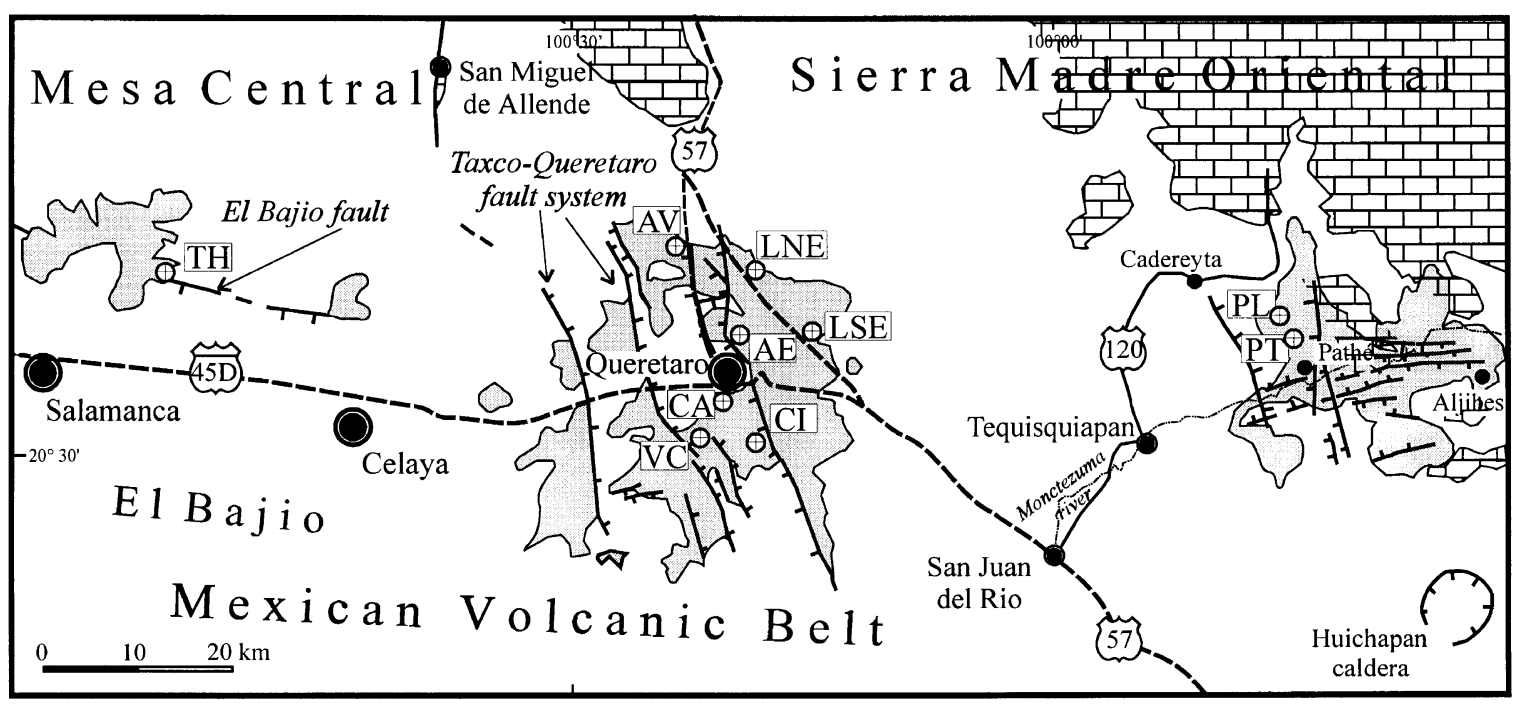

Fig. 4. Geologic sketch map of outcrops of upper Miocene mafic lavas and main faults in the Guanajuato, Queretaro and Hidalgo states (from Ferrari et al., 2000). Boxed pattern indicates the Mesozoic sedimentary succession of the Sierra Madre Oriental.

samples were obtained at the very bottom of flows with the hope of collecting samples with the finest grained material. At a few, small outcrops, only 4-6 samples were collected. Three samples were taken from the apparently altered part of the unit PL. Due to their distinct paleomagnetic directions, we decided to identify this result as a different unit PL (bis). Cores were obtained with a gasoline-powered portable drill, and then oriented in most cases with a magnetic compass (after testing that it was not affected by the remanent magnetization of the outcrop).

\section{Rock Magnetic Properties}

\subsection{Continuous thermomagnetic curves}

Low-field susceptibility measurements (using Bartington MS2 system), performed on one sample per flow, yield two different types of behavior. More than half of the curves show the presence of a single magnetic/ferrimagnetic phase with Curie point compatible with relatively low-Ti titanomagnetite (Fig. 5A, sample BRS-7a). However, the cooling and heating curves are not perfectly reversible. Microscopic observations on polished sections also show that the main 

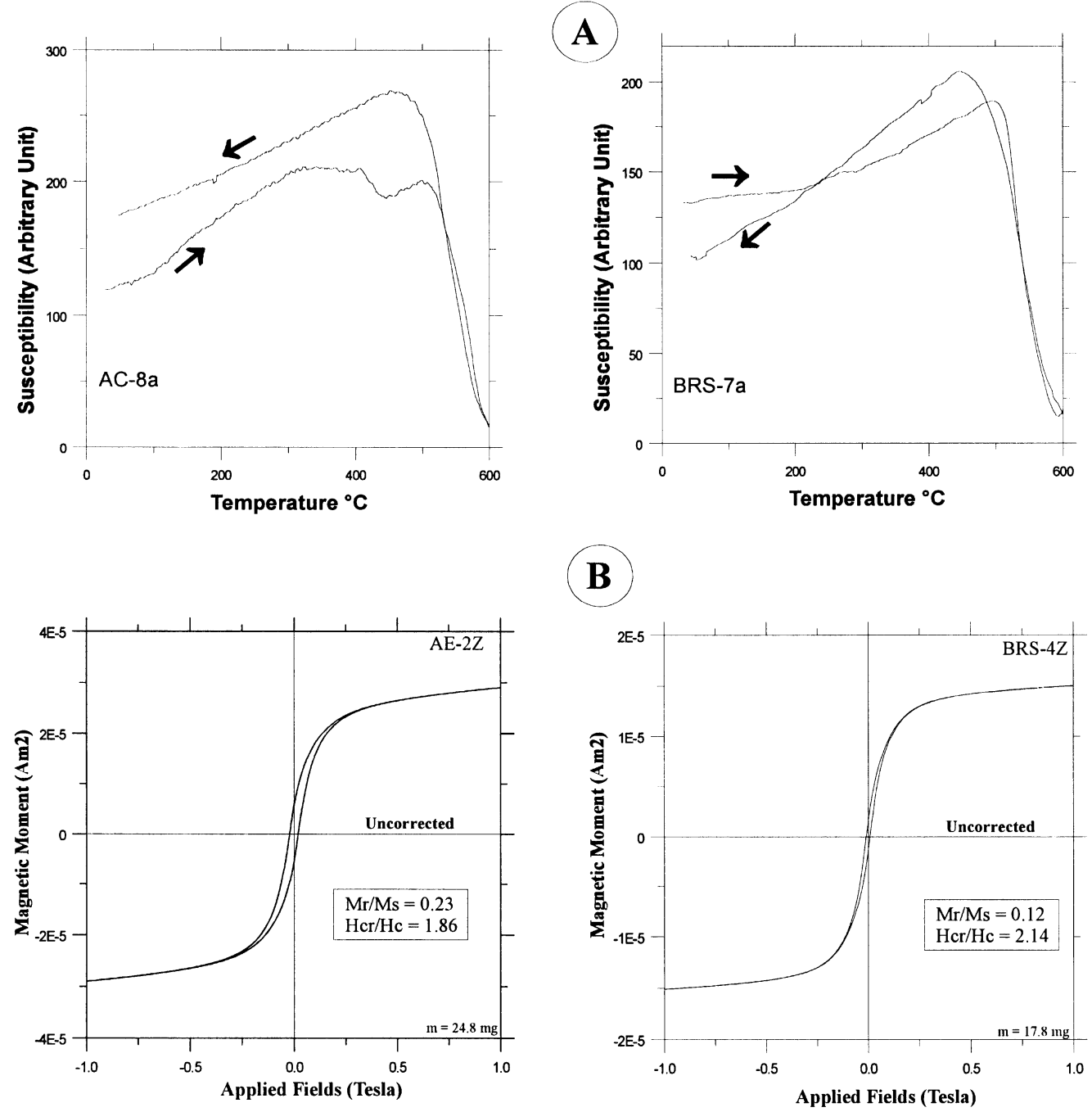

Fig. 5. A) Susceptibility versus temperature (in air) curves of representative samples. The arrows indicate the heating and cooling curves. B) Typical examples of hysteresis loops (uncorrected) of small chip samples from the studied volcanic flows.

magnetic mineral is low-Ti titanomagnetite associated with exsolved ilmenite, probably formed as a result of oxidation of titanomagnetite during initial cooling. These intergrowths typically develop higher than $600^{\circ} \mathrm{C}$ (Haggerty, 1976) and consequently, the NRM (natural remanent magnetization) carried by these samples should be a thermoremanent (TRM) magnetization.

In other cases, mainly flows from the Los Altos region, yield two different thermomagnetic phases during heating (Fig. 5A, sample AC-8a). The lower Curie point ranges between $380-420^{\circ} \mathrm{C}$, and the highest one is about $580^{\circ} \mathrm{C}$. The cooling curve shows only a single phase, with a Curie temperature close to that of magnetite. Such irreversible curves can be explained by titanomaghemite, which probably transformed into magnetite (Readman and O'Reilly, 1972; Özdemir, 1987) during heating. Both experimental and theoretical studies (Heider and Dunlop, 1987; Nishitani and Kono, 1989; Özdemir and Dunlop, 1989; Goguitchaichvili et al., 2000) show that chemical remagnetization by maghemitization records have the same direction as the original TRM. Consequently, paleodirections were most probably unaffected by alteration.

\subsection{Hysteresis experiments}

Hysteresis measurements were performed on samples from all flows using an AGFM 'Micromag', in fields up to $1 \mathrm{~T}$. Curves were rather symmetrical in all cases (Fig. 5B). Near the origin, no potbellied and wasp-waisted behavior (Tauxe et al., 1996) was detected, which probably reflects very restricted dual ranges of the opaque mineral coercivities. IRM (isothermal remanent magnetization) acquisition curves (not shown) were found very similar for all samples. Saturation is reached in moderate fields of the order of 100-150 mT, which reveals that a cubic phase is principal remanence carrier. Based on the ratios of hysteresis parameters, all samples fall in the pseudo-singledomain (PSD) grain size region, probably indicating a mixture of multidomain (MD) and a significant amount of singledomain (SD) grains.

\section{Paleomagnetism}

\subsection{Methods}

Remanence measurements were made using a Molspin spinner magnetometer (sensitivity $\sim 10^{-8} \mathrm{Am}^{2}$ ). Stepwise alternating field (AF) demagnetization used a home made AF demagnetizer providing fields up to $200 \mathrm{mT}$. Stepwise 

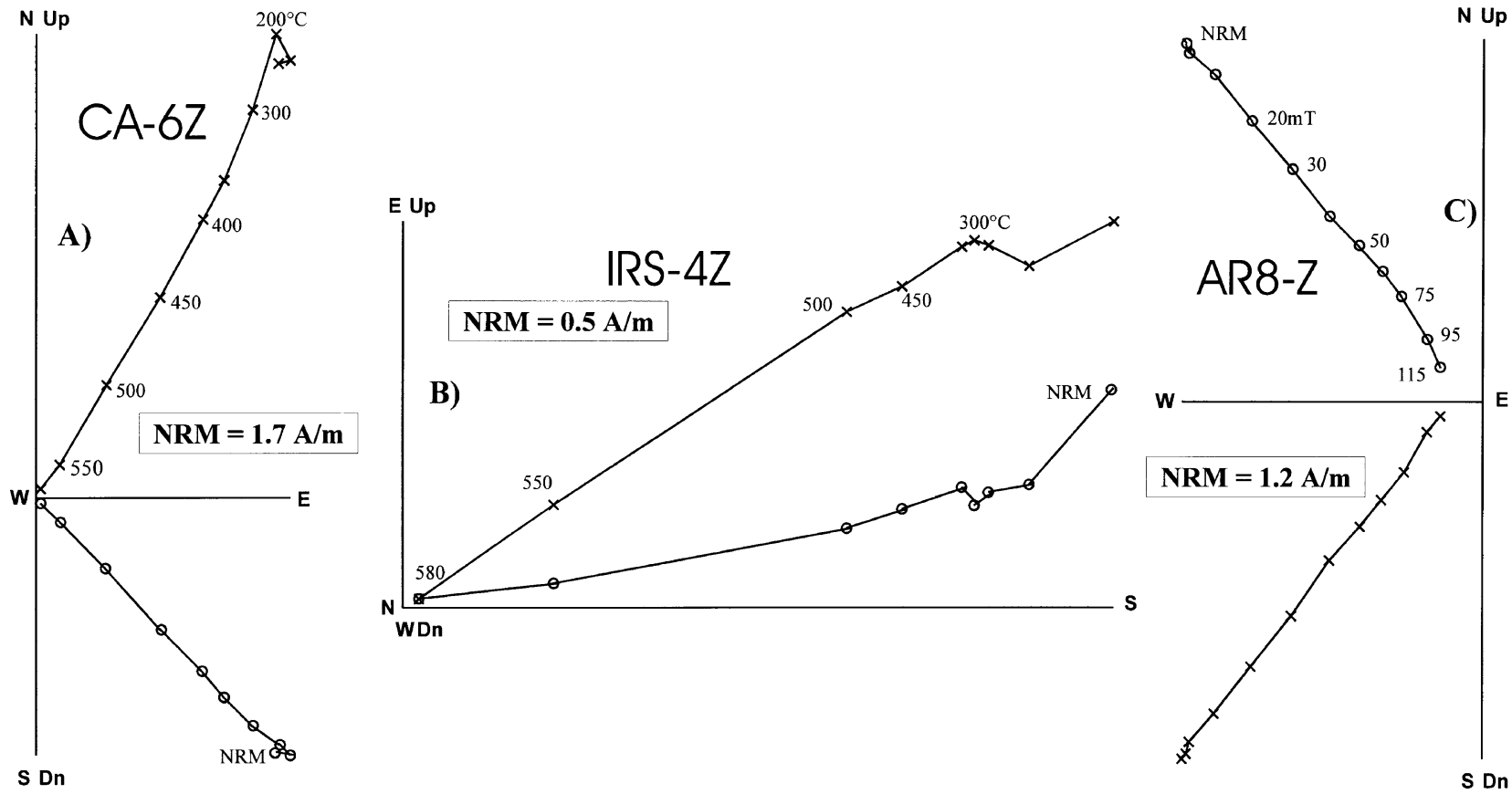

Fig. 6. Orthogonal vector plots of stepwise thermal or alternating field demagnetization of representative samples yielding mainly one component magnetization (stratigraphic coordinates). The numbers refer either to the temperatures in ${ }^{\circ} \mathrm{C}$ or to peak alternating fields in $\mathrm{mT}$. O-projections into the horizontal plane, x-projections into the vertical plane.
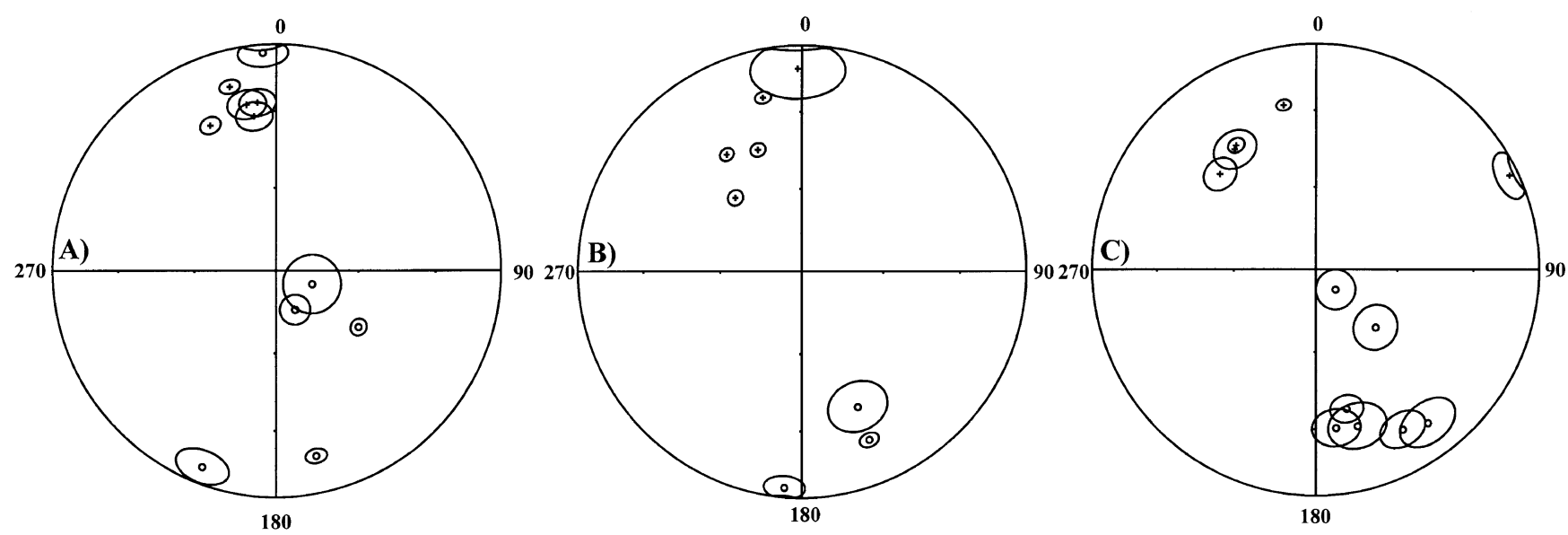

Fig. 7. Equal area projections of the flow mean characteristic paleodirections for three localities (A: Queretaro, B: Los Altos, C: Guadalajara). Circles/Crosses denote upper/lower hemisphere projections.

thermal demagnetization to $600^{\circ} \mathrm{C}$ was carried out using a Schonstedt furnace with a residual magnetic field of 20 to $25 \mathrm{nT}$. Heatings were performed in air. After each heating step, the low field susceptibility at room temperature was measured using a Bartington MS2 susceptibility meter.

A characteristic magnetization was determined by the least squares method (Kirschvink, 1980), with 4 to 9 points used for this determination. The directions were averaged by flow and the statistical parameters calculated assuming a Fisherian distribution.

\subsection{Demagnetization}

All 238 samples (i.e. one specimen per sample) were progressively demagnetized. Typically, 4 to 10 samples per flow were subjected to thermal or AF demagnetization, except unit
PL (bis), for which we had only 3 oriented samples. Most samples carry essentially a single component magnetization, observed both upon thermal or alternating field treatment (Fig. 6). A generally small secondary component, probably of viscous origin, is sometime present and easily removed (Figs. 8A and B). The majority of the remanence was removed at temperatures between 500 and $550^{\circ} \mathrm{C}$, which is common for Ti-poor titanomagnetite resulting from oxyexsolution. These observations are compatible with thermomagnetic experiments. The median destructive fields (MDF) range mostly from 30 to $40 \mathrm{mT}$ pointing to single-domain (SD) magnetic grains as remanence carriers (Dunlop and Özdemir, 1997). Higher coercivity components (MDF more than $100 \mathrm{mT}$ ) were found for unit AE. Few samples showed 
Table 1. Unit mean directions of remanence and corresponding VGP positions for all flows. $N$, number of treated samples; $n$, number of specimens used for calculation; Dec, Declination; Inc, Inclination. $k$ and $\alpha_{95}$ : precision parameter and radius of $95 \%$ confidence cone of Fisher statistics, $\delta$ : angular distance from the normal dipole direction. Pol, Magnetic polarity, Plat/Plong: Latitude/Longitude of VGP position.

\begin{tabular}{|c|c|c|c|c|c|c|c|c|c|c|c|c|}
\hline Flow & Location & Lat & Long & $n \backslash N$ & Dec & Inc & $k$ & $\alpha_{95}$ & $\delta$ & Pol & Plat & Plong \\
\hline \multicolumn{13}{|c|}{ Queretaro } \\
\hline $\mathrm{AE}$ & Queretaro airport & $20^{\circ} 37.130$ & $100^{\circ} 22.952$ & $8 \backslash 8$ & 335.3 & 30.1 & 263.1 & 3.4 & 21.2 & $\mathrm{~N}$ & 66.1 & 163.7 \\
\hline AV & Sta. Rosa Jauregui, Qro & $20^{\circ} 43.708$ & $100^{\circ} 26.501$ & $10 \backslash 10$ & 345.6 & 17.2 & 237.3 & 3.1 & 20.4 & $\mathrm{~N}$ & 71.9 & 131.9 \\
\hline $\mathrm{CA}$ & Queretaro toll house & $20^{\circ} 34.181$ & $100^{\circ} 29.005$ & $10 \backslash 10$ & 124.4 & -53.4 & 418.6 & 2.4 & 136.1 & $\mathrm{I}$ & -39.3 & 17.3 \\
\hline CI & Cerro Cimatario, Qro. & $20^{\circ} 31.217$ & $100^{\circ} 19.932$ & $6 \backslash 8$ & 200.9 & -8.1 & 100.1 & 7.7 & 148.5 & $\mathrm{R}$ & -64 & 205.6 \\
\hline LNE & Highway to S.M. Allende & $20^{\circ} 43.061$ & $100^{\circ} 21.714$ & $8 \backslash 8$ & 349.8 & 26.3 & 87.4 & 6.1 & 11.1 & $\mathrm{~N}$ & 78.3 & 137.5 \\
\hline LSE & Highway to S.M. Allende & $20^{\circ} 40.857$ & $100^{\circ} 18.645$ & $8 \backslash 8$ & 351.8 & 31.6 & 84.6 & 5.9 & 7.1 & $\mathrm{~N}$ & 81.6 & 148.1 \\
\hline PL & North of Pathé, Hgo. & $20^{\circ} 40.599$ & $99^{\circ} 41.965$ & $5 \backslash 5$ & 356.4 & -4 & 132.2 & 6.7 & 37.2 & $\mathrm{~N}$ & 67.3 & 89.9 \\
\hline PL (bis) & North of Pathé, Hgo. & $20^{\circ} 40.599$ & $99^{\circ} 41.965$ & $3 \backslash 3$ & 110.8 & -76.1 & 139.1 & 10.5 & 126.3 & $\mathrm{I}$ & -27.4 & 52.7 \\
\hline PT & North of Pathé, Hgo. & $20^{\circ} 39.909$ & $99^{\circ} 41.920$ & $8 \backslash 8$ & 167.7 & -17.4 & 254 & 3.2 & 160.9 & $\mathrm{R}$ & -73.5 & 308.3 \\
\hline TH & N of Juventino Rosas & $20^{\circ} 42.168$ & $101^{\circ} 02.584$ & $8 \backslash 8$ & 353.6 & 26.1 & 94.7 & 5.7 & 8.9 & $\mathrm{~N}$ & 80.9 & 122.4 \\
\hline $\mathrm{VC}$ & Villa Corregidora & $20^{\circ} 39.965$ & $100^{\circ} 25.606$ & $6 \backslash 6$ & 154.1 & -74.3 & 155 & 5.4 & 136.8 & $\mathrm{R}$ & -46 & 62.3 \\
\hline \multicolumn{13}{|c|}{ Los Altos } \\
\hline $\mathrm{AC}$ & Atotonilco, Jal. & $20^{\circ} 29.880$ & $102^{\circ} 27.450$ & $8 \backslash 8$ & 157.8 & -20.7 & 339.5 & 3 & 156.8 & $\mathrm{R}$ & -66.6 & 326.9 \\
\hline $\mathrm{AR}$ & W of Arandas, Jal. & $20^{\circ} 42.130$ & $102^{\circ} 19.660$ & $9 \backslash 9$ & 326.9 & 38.2 & 445.8 & 2.4 & 27.3 & $\mathrm{~N}$ & 59.1 & 176.8 \\
\hline $\mathrm{CM}$ & Ayotlán, Jal. & $20^{\circ} 33.060$ & $102^{\circ} 18.770$ & $10 \backslash 10$ & 317.5 & 53.6 & 302.7 & 2.8 & 36.4 & $\mathrm{~N}$ & 50.1 & 197.2 \\
\hline $\mathrm{CP}$ & Cerro Pelon quarry & $20^{\circ} 40.530$ & $102^{\circ} 13.900$ & $9 \backslash 9$ & 157.2 & -35.2 & 32.2 & 9.9 & 161 & $\mathrm{R}$ & -68.6 & 349.3 \\
\hline $\mathrm{LC}$ & Ocotlán toll house, Jal. & $20^{\circ} 24.100$ & $102^{\circ} 44.140$ & $8 \backslash 8$ & 184.7 & -4.7 & 99.4 & 5.6 & 151.4 & $\mathrm{R}$ & -71.5 & 243.6 \\
\hline LP & Presa Huascato, Jal. & $20^{\circ} 29.310$ & $102^{\circ} 14.000$ & $10 \backslash 10$ & 339.9 & 42.2 & 360.3 & 2.5 & 18.3 & $\mathrm{~N}$ & 71 & 184.1 \\
\hline LR & Atotonilco, Jal. & $20^{\circ} 31.410$ & $102^{\circ} 26.140$ & $8 \backslash 8$ & 347.2 & 22.2 & 736.1 & 2.1 & 15.6 & $\mathrm{~N}$ & 74.9 & 134.2 \\
\hline SJG & $\mathrm{N}$ of Atotonilco & $20^{\circ} 41.200$ & $102^{\circ} 32.660$ & $8 \backslash 10$ & 358.8 & 11.1 & 15.4 & 13.5 & 21.9 & $\mathrm{~N}$ & 75.1 & 82.3 \\
\hline MB* & Mesa del Burro & $20^{\circ} 40.500$ & $103^{\circ} 25.500$ & $6 \backslash 7$ & 5 & 33.8 & 59.1 & 8.8 & 4.3 & $\mathrm{~N}$ & 79.1 & 50.8 \\
\hline \multicolumn{13}{|c|}{ Guadalajara } \\
\hline AM2 & El Malacate & $21^{\circ} 09.670$ & $103^{\circ} 25.740$ & $7 \backslash 7$ & 167.4 & -36.8 & 122.1 & 5.5 & 169 & $\mathrm{R}$ & -78.2 & 342.3 \\
\hline AM1 & El Malacate & $21^{\circ} 09.330$ & $103^{\circ} 26.110$ & $6 \backslash 8$ & 164.9 & -28.9 & 66.9 & 9.4 & 166.4 & $\mathrm{R}$ & -74.3 & 325 \\
\hline BGCS1 & Cerro Mata, Zac. & $21^{\circ} 11.160$ & $103^{\circ} 27.280$ & $4 \backslash 4$ & 135.6 & -79.8 & 165.8 & 7.2 & 129.9 & $\mathrm{I}$ & -34.4 & 60.1 \\
\hline BGCS2 & Cerro Mata, Zac. & $21^{\circ} 11.160$ & $103^{\circ} 27.280$ & $5 \backslash 5$ & 151.1 & -20.1 & 110.2 & 7.3 & 151.2 & $\mathrm{R}$ & -60.1 & 330 \\
\hline BIRS & Rio Santiago canyon & $20^{\circ} 40.420$ & $103^{\circ} 11.370$ & $4 \backslash 4$ & 325.8 & 35.8 & 157.4 & 7.3 & 28.2 & $\mathrm{~N}$ & 58.1 & 171.9 \\
\hline $\mathrm{BM}$ & $\mathrm{N}$ of San Cristobal & $21^{\circ} 07.890$ & $103^{\circ} 25.180$ & $5 \backslash 6$ & 133.9 & -59.5 & 90.1 & 8.1 & 139.9 & $\mathrm{R}$ & -46.4 & 24.1 \\
\hline BRS & Road to Ixtlahuaca & $20^{\circ} 40.550$ & $103^{\circ} 10.230$ & $8 \backslash 8$ & 348.7 & 26.6 & 586.6 & 2.3 & 11.7 & $\mathrm{~N}$ & 77.5 & 138.2 \\
\hline BRS1 & Road to Ixtlahuaca & $20^{\circ} 40.040$ & $103^{\circ} 10.830$ & $6 \backslash 6$ & 143.4 & -16.4 & 55.4 & 9.1 & 143.1 & $\mathrm{R}$ & -53.6 & 306.4 \\
\hline IRS & Road to Ixtlahuaca & $20^{\circ} 40.300$ & $103^{\circ} 11.160$ & $4 \backslash 5$ & 172.6 & -29.9 & 144.4 & 7.7 & 173 & $\mathrm{R}$ & -81.7 & 316.3 \\
\hline ISG & San Gaspar & $20^{\circ} 41.500$ & $103^{\circ} 10.530$ & $8 \backslash 10$ & 64.3 & 4.2 & 83.6 & 6.6 & 66.3 & $\mathrm{I}$ & 24.8 & 354.3 \\
\hline SCB1 & San Cristobal & $21^{\circ} 02.540$ & $103^{\circ} 25.540$ & $9 \backslash 9$ & 327.1 & 34.8 & 336.2 & 2.8 & 27.3 & $\mathrm{~N}$ & 59.1 & 170.4 \\
\hline SCB2 & San Cristobal & $21^{\circ} 03.400$ & $103^{\circ} 25.640$ & $6 \backslash 6$ & 314.7 & 39.7 & 188.7 & 5.9 & 36.7 & $\mathrm{~N}$ & 47.9 & 178.3 \\
\hline
\end{tabular}

*Site MB represent very young (most probably late Bruhnes) lava flow and yielded paleodirections close to the present day field.

more complex or 'unstable' remanence and no primary magnetization was determined.

4.3 Directions of characteristic remanent magnetization

The flow mean paleodirections are overall well-determined (Table 1, Fig. 7). Almost all $\alpha_{95}$ values are less than $10^{\circ}$, except the unit PL (bis) where we had only 3 samples and SJG, which seems to be affected by lightning.
Six normal, three reverse and two intermediate polarity flows were recognized for Queretaro volcanic field (Table 1). Their correlation with geomagnetic polarity time scale (GPTS) is discussed below. In this paper, we formally use the paleolatitude of $45^{\circ}$ as a cut-off angle to separate the paleosecular variation and intermediate geomagnetic regime (McElhinny and McFadden, 1997). In absence of more detailed paleomagnetic coverage, we are not sure that the in- 

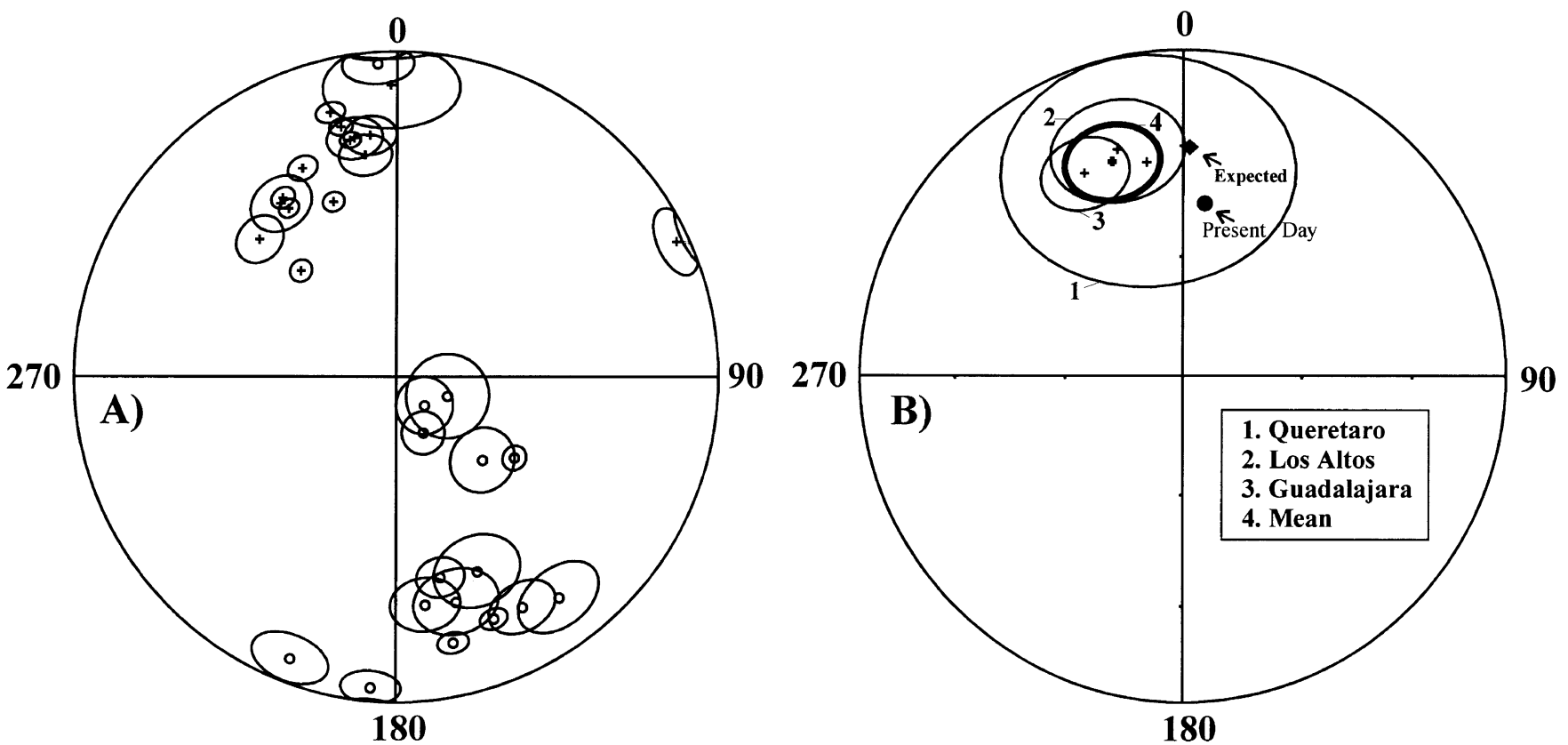

Fig. 8. Equal area projection of the mean directions for all flows and for the three groups of sites as indicated in Table 3.

Table 2. Between flow average directions and VGPs for the Queretaro, Los Altos and Guadalajara sites. $S$ is the total between flow dispersion of average flow VGP. $S_{u}$ and $S_{l}$ are 95 per cent confidence limits for $S$ after Cox (1969). Intermediate directions (flows: CA, PL (bis) and BGCS1) are discarded (see text). In addition, four units (AM1, AM2, MB and ISG) were also discarded for the analyses because their inadequate ages (see text and Table 3).

\begin{tabular}{lcccccccccccc}
\hline Locality & $N$ & Inc & Dec & \multicolumn{1}{c}{$k$} & $\alpha_{95}$ & Plat & Plong & $K$ & $\alpha_{95}$ & $S$ & $S_{l}$ & $S_{u}$ \\
\hline Queretaro & 9 & 33.7 & 350.8 & 3 & 33.2 & 80.6 & 140 & 14 & 14.2 & 21.7 & 16.6 & 31.2 \\
Los Altos & 8 & 29.2 & 343.5 & 15 & 14.8 & 72.5 & 159 & 20 & 12.6 & 18.1 & 13.7 & 26.8 \\
Guadalajara & 8 & 33.5 & 330.7 & 21 & 12.4 & 63.4 & 164 & 18 & 13.5 & 19.2 & 14.5 & 28.4 \\
All & 25 & 32.4 & 341.2 & 7 & 11.6 & 72.7 & 158 & 16 & 7.5 & 20.3 & 17 & 25.2 \\
\hline
\end{tabular}

termediate VGP's found in this study have a geomagnetic significance. Los Altos region yielded mostly normal polarity magnetization except flows $\mathrm{AC}, \mathrm{CP}$ and $\mathrm{LC}$, which are reversely magnetized. Six reversed, four normal and two intermediate polarity flows were recognized in Guadalajara volcanic field (Fig. 7 and Table 1)

\section{Discussion and Conclusions}

In general the polarity obtained for the flows studied is consistent with their stratigraphic position and with absolute age determinations for each site (Fig. 9). Combining the available geochronologic data with the polarity of the paleomagnetic samples obtained in this study, better constraints of the age of emplacement can be achieved (Table 3, Fig. 9).

Lava flows sampled in the northern transect of the Rio Grande de Santiago (BGC, BM and SCB series) may all be put into Anomaly 5. The older part of the sequence, sampled in the northern side of the valley, was reversely magnetized, and, in accordance with the age provided by Moore et al. (1994), should correspond to chron C5r.1r (10.9411.05; Cande and Kent, 1995). The polarity of the rest of the succession was normal, and coincides with chron C5n.2n (9.92-10.94 Ma). The second transect along the Rio Santi- ago valley (BRS and BIRS samples) is less well dated but if one consider the ages provided by Watkins et al. (1971), recalculated with the constants of Steiger and Jäger (1977), the observed polarity appear to belong to anomaly 4A and to chron C4Ar.1r to C4Ar.2r (9.02-9.58 Ma) with samples BIRS and BRS corresponding to the short events of normal polarity C4Ar.1n.

Sites sampled in the Los Altos de Jalisco region also span Anomaly 4A and 5 (Table 3). The large experimental error $(2 \sigma=1-2 \mathrm{Ma})$ of some of the available ages suggests that they are probably not very reliable. The real age may be inferred from the obtained polarity. Sites AC and CP were dated at $13.5 \pm 1.3 \mathrm{Ma}$ and $12.0 \pm 2.0 \mathrm{Ma}$ by CastilloHernandez and Romero-Rios (1991) and Verma et al. (1987); however, according with the stratigraphic position and the obtained polarity the real age probably fall within chron $\mathrm{C} 5 \mathrm{r}$, in the range 10.94-11.93 Ma. Similarly, site SJG, dated at $11.0 \pm 2.0 \mathrm{Ma}$ by Verma et al. (1987), could belong to chron C5n.2n (9.92-10.94 Ma) as most of the other sampled sites. The basaltic flow sampled north of Salamanca (TH) also belongs to chron C5n.2n (Table 3). However, the basalts exposed to the east, in the Queretaro and Pathe areas are distinctly younger, being emplaced within Anomaly 4 and, 


\section{Guadalajara region}

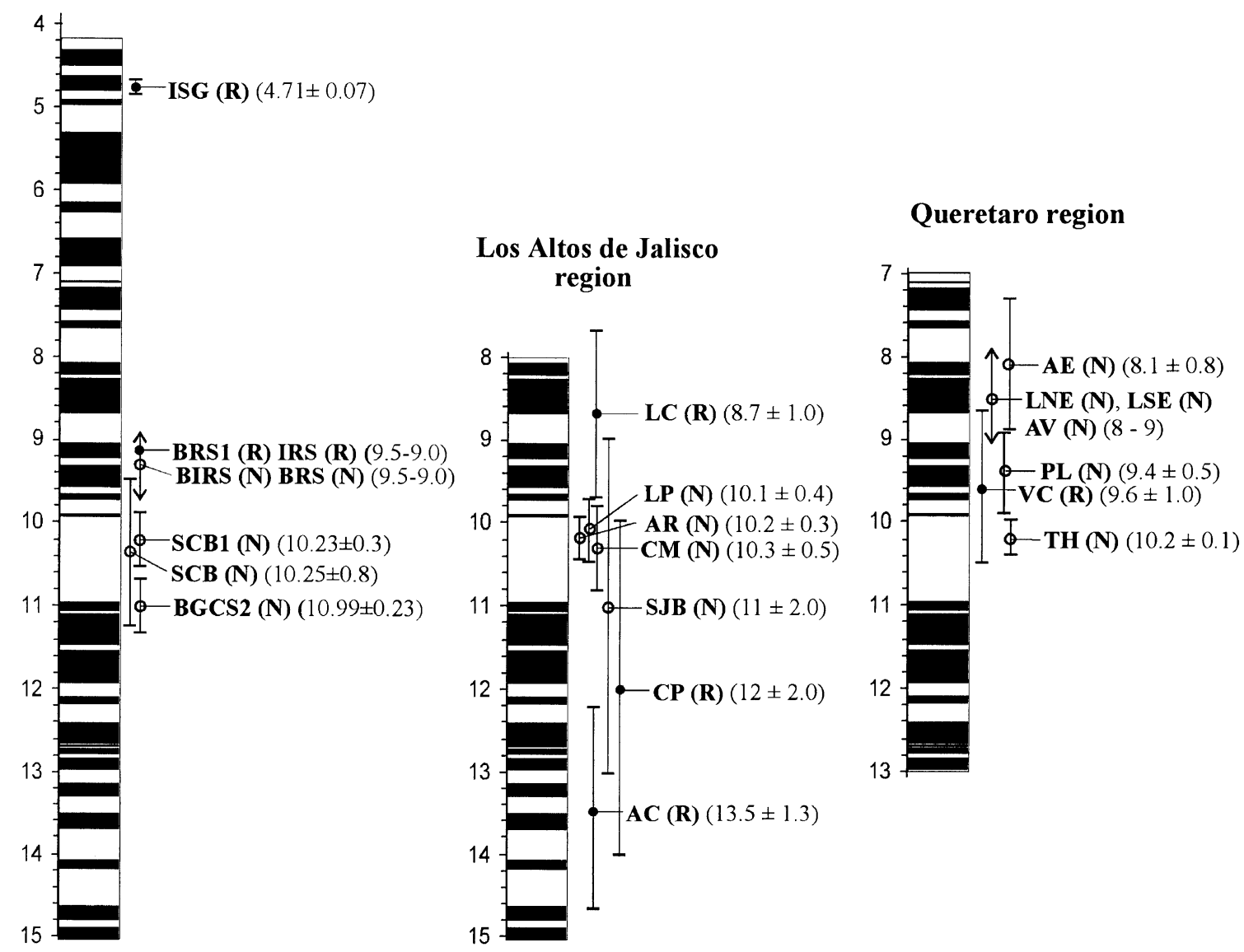

Fig. 9. Summary of the results from the three studied regions with possible relation with the geomagnetic scale of Cande and Kent (1995). Absolute ages are reported with error bar. Arrows indicate the possible age range of some sample based on correlation of geologic units.

likely between chron $\mathrm{C} 4 \mathrm{n}$ and $\mathrm{C} 5 \mathrm{n} .1 \mathrm{n}$.

In conclusion, combining the magnetostratigraphic and isotopic age data set, the volcanic activity in the Rio Grande de Santiago and Los Altos de Jalisco regions appears to have taken place between 9 and $11 \mathrm{Ma}$ and the volcanism in the Queretaro and Pathé areas took place between 7.4 and 9.8 Ma, thus revealing a marked eastward migration of volcanism with time.

Our paleomagnetic data has an unfortunately large dispersion (Fig. 8 and Table 2). We calculated mean directions in several ways. In order to omit transitional directions in the calculation, a cut-off angle is used to separate assumed paleosecular variation and intermediate field periods. Using of a correct cut-off angle is still controversial. Camps and Prévot (1996) showed that, if the angular distance from the dipole direction ( $\delta$ on Table 1 ) exceeds $40^{\circ}$, the directions should be regarded as intermediate. McElhinny and McFadden (1997), analysing worldwide paleomagnetic data, used VGP paleolatitude of $45^{\circ}$ as a limit of paleosecular variations. This cut-off angle was used in this study. Queretaro volcanic field yield the mean directions of $I=33.7^{\circ}, D=350.8^{\circ}$, $k=3.4, \alpha_{95}=33.2$. Los Altos region provide $I=29.2^{\circ}$, $D=343.5^{\circ}, k=15, \alpha_{95}=14.8$ and Guadalajara region $I=33.5^{\circ}, D=330.7^{\circ}, k=20.8, \alpha_{95}=12.4$. Using all data (25 flows), we obtained mean inclination of $32.4^{\circ}$ and mean declination of $341.2^{\circ}$. The mean inclination (Fig. 8 and Table 2) is, in each determination, in good agreement with the expected inclination for the late Miocene, as derived from reference poles given by Besse and Courtillot (1991) for North America. The declination, however, is significantly different from that expected $\left(D=1.2^{\circ}\right)$. The results from Guadalajara region shows the highest deviation in declination (Table 2). The mean direction calculated from all data suggest a mean tectonic counterclockwise rotation of about $20^{\circ}$. The declination deviation could be the consequence of local block rotations. However, our data set presents apparently large dispersion (Table 2) and is not sufficiently robust to enable an accurate determination of the variations in the magnitude of the rotations within the studied area. Counterclockwise rotations in central Mexico were previously recognized by Urrutia-Fucugauchi (1976) and later supported by additional studies (Urrutia-Fucugauchi, 1981; UrrutiaFucugauchi and Böhnel, 1988). More recently, UrrutiaFucugauchi and Rosas-Elguera (1994) reported about $15^{\circ}$ counterclockwise rotation for latest Miocene to Quaternary lavas in the Lake Chapala area, south of the Los Altos de Jalisco region (Fig. 3).

These available paleomagnetic data, altogether with our new results may be explained by rotations of shallow crustal blocks by variable left-lateral shear across the studied region. Most sites along the Rio Grande de Santiago north of Guadalajara and in the Los Altos de Jalisco region lie 
Table 3. Summary of the available isotopic age determinations for the studied volcanic flows and their possible relation to the Cande and Kent (1995) geomagnetic polarity time scale.

\begin{tabular}{|c|c|c|c|c|c|}
\hline \multicolumn{6}{|c|}{ Sample age } \\
\hline Site & $\begin{array}{l}\text { Published } \\
\text { age (Ma) }\end{array}$ & Ref. & Polarity & Possible Chron & $\operatorname{Age}(\mathrm{Ma})^{(1)}$ \\
\hline \multicolumn{6}{|c|}{ Guanajuato, Queretaro and Hidalgo } \\
\hline $\mathrm{AE}$ & $8.1 \pm 0.8$ & 1 & $\mathrm{~N}$ & $\mathrm{C} 4 \mathrm{n}-\mathrm{C} 4 \mathrm{r} .1 \mathrm{n}$ & $7.43-8.25$ \\
\hline $\mathrm{AV}$ & $\sim 8-9$ & $*$ & $\mathrm{~N}$ & $\mathrm{C} 4 \mathrm{n}-\mathrm{C} 4 \mathrm{r} .1 \mathrm{n}$ & $7.43-8.25$ \\
\hline $\mathrm{CA}$ & $\sim 8-9$ & $*$ & I & - & - \\
\hline $\mathrm{CI}$ & undated & & $\mathrm{R}$ & $\mathrm{C} 3 \mathrm{Br}-\mathrm{C} 4 \mathrm{n} .1 \mathrm{r}$ & $<7.65 ?$ \\
\hline LNE & $\sim 8-9$ & $*$ & $\mathrm{~N}$ & $\mathrm{C} 4 \mathrm{n}-\mathrm{C} 4 \mathrm{r} .1 \mathrm{n}$ & $7.43-8.25$ \\
\hline LSE & $\sim 8-9$ & $*$ & $\mathrm{~N}$ & $\mathrm{C} 4 \mathrm{n}-\mathrm{C} 4 \mathrm{r} .1 \mathrm{n}$ & $7.43-8.25$ \\
\hline PL & $9.4 \pm 0.5$ & 2 & $\mathrm{~N}$ & C4Ar.1n-C5n.1n & $9.23-9.88$ \\
\hline PL' & $9.4 \pm 0.5$ & 2 & I & - & - \\
\hline PT & $9.4 \pm 0.5$ & 2 & $\mathrm{R}$ & $\mathrm{C} 4 \mathrm{n} .1 \mathrm{r}$ & $7.56-7.65$ \\
\hline TH & $10.2 \pm 0.1$ & 3 & $\mathrm{~N}$ & C $5 n .2 n$ & $9.92-10.94$ \\
\hline $\mathrm{VC}$ & $9.6 \pm 1.0$ & 4 & $\mathrm{R}$ & C4Ar.1r-C5n.1r & $9.02-9.92$ \\
\hline \multicolumn{6}{|c|}{ Los Altos de Jalisco } \\
\hline $\mathrm{AC}$ & $13.5 \pm 1.3$ & 6 & $\mathrm{R}$ & C5r.1r-C5r.3r? & $10.94-11.93$ \\
\hline AR & $10.2 \pm 0.3$ & 6 & $\mathrm{~N}$ & C $5 n \cdot 2 n$ & $9.92-10.94$ \\
\hline $\mathrm{CM}$ & $10.3 \pm 0.5$ & 5 & $\mathrm{~N}$ & C5n.2n & $9.92-10.94$ \\
\hline $\mathrm{CP}$ & $12.0 \pm 2.0$ & 7 & $\mathrm{R}$ & C5r.1r-C5Abr & $10.94-11.93$ \\
\hline $\mathrm{LC}$ & $8.7 \pm 1.0$ & 8 & $\mathrm{R}$ & C4r.1r-C4Ar.3r & $8.07-9.74$ \\
\hline LP & $10.1 \pm 0.4$ & 5 & $\mathrm{~N}$ & $\mathrm{C} 5 \mathrm{n} .2 \mathrm{n}$ & $9.92-10.94$ \\
\hline LR & $\sim 10-11$ & $*$ & $\mathrm{~N}$ & C $5 n \cdot 2 n ?$ & $9.92-10.94$ \\
\hline SJG & $11.0 \pm 2.0$ & 8 & $\mathrm{~N}$ & C $5 n \cdot 2 n ?$ & $9.92-10.94$ \\
\hline $\mathrm{MB}^{*}$ & - & & $\mathrm{N}$ & - & - \\
\hline \multicolumn{6}{|c|}{ Rio Grande de Santiago (Guadalajara) } \\
\hline AM2 & $21.6 \pm 0.3$ & 9 & $\mathrm{R}$ & C6Ar & $21.32-21.76$ \\
\hline AM1 & $21.6 \pm 0.3$ & 9 & $\mathrm{R}$ & C6Ar & $21.32-21.76$ \\
\hline BGCS1 & $10.99 \pm 0.23$ & 10 & I & - & - \\
\hline BGCS2 & $10.99 \pm 0.23$ & 10 & $\mathrm{R}$ & C5r.1r & $10.94-11.05$ \\
\hline BIRS & $9.5-9.0$ & 11 & $\mathrm{~N}$ & C4Ar. $1 \mathrm{n}-\mathrm{C} 4 \mathrm{Ar} .2 \mathrm{n}$ & $9.23-9.64$ \\
\hline BM & $\sim 10-11$ & $*$ & $\mathrm{R}$ & C5r.1r? & $10.94-11.05$ \\
\hline BRS & $9.5-9.0$ & 11 & $\mathrm{~N}$ & C4Ar.1n-C4Ar.2n & $9.23-9.64$ \\
\hline BRS1 & $9.5-9.0$ & 11 & $\mathrm{R}$ & C4Ar.1r-C4Ar.2r & $9.02-9.58$ \\
\hline IRS & $9.5-9.0$ & 11 & $\mathrm{R}$ & C4Ar.1r-C4Ar.2r & $9.02-9.58$ \\
\hline ISG & $4.71 \pm 0.07$ & 12 & I & - & - \\
\hline SCB1 & $10.23 \pm 0.34$ & 10 & $\mathrm{~N}$ & C $5 n \cdot 2 n$ & $9.92-10.94$ \\
\hline $\mathrm{SCB}$ & $10.25 \pm 0.82$ & 10 & $\mathrm{~N}$ & C5n.2n & $9.92-10.94$ \\
\hline
\end{tabular}

References: 1 Pasquaré et al., 1991; 2 Jacobo-Albarrán, 1986; 3 Hasenaka et al., 1994; 4 Murillo-Muñeton and Torres-Vargas, 1987; 5 Castillo and Romero, 1991; 6 Nixon et al., 1987; 7 Verma et al., 1987; 8 Rosas and Urrutia, 1998; 9 Ferrari, unpublished; 10 Moore et al., 1994 ; 11 Watkins et al., 1971; 12 Gilbert et al., 1985. * inferred from stratigraphic relations, ${ }^{(1)}$ Based on Cande and Kent, 1995.

close to two ENE-WSW trending left-lateral transtensional fault zones (Figs. 2 and 3) (Ferrari et al., 2000). The first system runs from Ixtlahuacán to San Miguel el Alto and is characterized by several NNE trending en echelon splays, indicative of a left-lateral component of motion (Figs. 2 and 3). The second transtensional fault system runs from Ocotlán to Cuerámaro through Atotonilco (Fig. 3) and fault planes with a left-slip component of offset were observed at many sites (Ferrari et al., 2000). The westward continuation of this system could be responsible for the counterclockwise rotation observed also in the Chapala area (Urrutia-Fucugauchi and Rosas-Elguera, 1994). Block rotation associated to these transtensional fault systems is probably responsible for the observed declination discrepancies. The relative scatter of the observed rotations in the three regions may be explained by considering that the fault system affects a rather wide belt that is fractured in several small blocks with variable internal rotation.

In the case of the Queretaro area the counterclockwise rotation with respect to that expected for North America is 
relatively small. This may be related to a minor left-lateral component of motion along the NNW-SSE trending TaxcoQueretaro and Pathé faults system (Fig. 4), which could be expected if these faults were reactivated by arc normal extension. Alternatively, it can be due to the left-lateral transtension along the ENE-WSW faults of the Cuitzeo lake region (Pasquaré et al., 1991), which continue to the ENE up to the Queretaro and Pathé areas (Fig. 4).

In conclusion, we propose that the paleomagnetic data reported here are consistent with an increasing counterclockwise rotation of upper Miocene rocks in central Mexico, from the Pathé area to the west, which could be related to intra-arc left-lateral transtension. In any case, more comprehensive work on these areas is required to understand the details of the shearing tectonics, which accompanied the early development of the Mexican Volcanic Belt.

Acknowledgments. This study was mainly supported by grant to LA from UNAM-PAPIIT IN122898 Universidad de GuadalajaraUNAM Academic Exchange Program and internal grant of the Instituto de Geofísica, UNAM. AG acknowledges support from CONACYT project J32727-T. LF was supported by grant UNAM-PAPIIT IN108196. JRE was supported by Departamento de Ingeniería Civil y Topografía (Gonzalo Herrera Serrano) and CONACyT I 30017-T. Laboratory measurements were carried out by J. A. Gonzalez and M. Espinosa. The authors wish to thank J. Wm. Geissmann and an anonymous referee for useful comments that greatly improved the manuscript.

\section{References}

Besse, J. and V. Courtillot, Revised and synthetic apparent polar wander paths of the African, Eurasian, North American and Indian Plates, and true polar wander since $200 \mathrm{Ma}$, J. Geophys. Res., 96, 4029-4050, 1991.

Camps, P. and M. Prèvot, A statistical model of the fluctuation in the geomagnetic field from paleosecular variation to reversal, Science, 273, 776-779, 1996.

Cande, S. C. and D. V. Kent, Revised calibration of the geomagnetic polarity time scale for the Late Cretaceous and Cenozoic, J. Geophys. Res., 100, 6093-6095, 1995.

Castillo-Hernandez, D. and F. Romero-Rios, Estudio geologico-regional de Los Altos, Jalisco y El Bajio: Comisión Federal de Electricidad, Gerencia de Proyectos Geotermoelectricos, Depto. Exploración, Open File Report, 02-91, 35 pp., 1991.

Cerca-Martínez, L. M., Relacion estratigrafica y geocronologica entre el volcanismo de la Sierra Madre Occidental y el Cinturon Volcanico Mexicano en la parte sur de la Sierra de Guanajuato, M. Sc. Thesis, Dept. of Geology, Centro de Investigación y Enseñanza Superior de Ensenada, Baja California, Mexico, 119 pp., 1998.

Damon, P. E., O. J. Nieto, and A. L. Delgado, Un plegamiento neogenico en Nayarit y Jalisco y evolucion geomorfica del Rio Grande de Santiago, Asociacion Ingenieros Mineros, Metalurgicos y Geologos de Mexico. Memoria Tecnica XIII, 156-191, 1979.

Dunlop, D. and Ö. Özdemir, Rock-Magnetism, Fundamentals and Frontiers, 573 pp., Cambrige University Press, 1997.

Ferrari, L., V. H. Garduño, F. Innocenti, P. Manetti, G. Pasquarè, and G. Vaggelli, A widespread mafic volcanic unit at the base of the Mexican Volcanic Belt between Guadalajara and Queretaro, Geofísica Internacional, 33, 107-124, 1994a.

Ferrari, L., V. H. Garduño, G. Pasquarè, and A. Tibaldi, Volcanic and tectonic evolution of central Mexico: Oligocene to Recent, Geofísica Internacional, 33, 91-105, 1994b.

Ferrari, L., M. Lopez-Martinez, G. Aguirre-Diaz, and G. Carrasco-Nuñez, Space-time patterns of Cenozoic arc volcanism in central Mexico: from the Sierra Madre Occidental to the Mexican Volcanic Belt, Geology, 27, 303-306, 1999.

Ferrari, L., S. Conticelli, C. Vaggelli, C. Petrone, and P. Manetti, Late Miocene mafic volcanism and intra-arc tectonics during the early development of the Trans-Mexican Volcanic Belt, Tectonophys., 318, 161-185, 2000.

Garduño, V. H., J. Spinnler, and E. Ceragioli, Geological and structural study of the Chapala Rift, state of Jalisco, Mexico, Geofísica Internacional, 32,
487-499, 1993.

Gilbert, C. M., G. A. Mahood, and I. S. E. Carmichael, Volcanic stratigraphy of the Guadalajara area, Mexico, Geofísica Internacional, 24, 169-191, 1985.

Goguitchaichvili, A., A. Chauvin, P. Roperch, M. Prèvot, M. Vergara, and H. Moreno, Paleomagnetism of the Miocene Farellones Formation in Chile, Geophys. J. Int., 140, 357-374, 2000.

Haggerty, S. E., Oxidation of opaque mineral oxides in basalts, in Oxide Minerals, Mineral. Soc. Amer, 3, 300 pp, 1976.

Hasenaka, T., K. Uto, S. Uchiumi, T. Yoshida, K. Ishikawa, and A. RamosSalinas, Science Report, Institute of Mineralogy, Petrology and Economic Geology, Faculty of Sciences, Tohoku University, 27, 43-53, 1994 (in Japanese with English abstract).

Heider, F. and D. J. Dunlop, Two types of chemical remanent magnetization during oxidation of magnetite, Phys. Earth Planet. Inter. 46, 24-45, 1987.

Jacobo-Albarrán, J., Estudio petrogenetico de las rocas igneas de la porción central del Eje Neovolcánico, Instituto Mexicano del Petroleo, Subdirección de Tecnología de Exploración, Open File Report, Proyecto C2006, 47 pp., 1986.

Kirschvink, J. L., The least-square line and plane and analysis of palaeomagnetic data, Geophys. J. R. Astron. Soc., 62, 699-718, 1980.

McElhinny, M. W. and P. L. McFadden, Paleosecular variation over the past 5 Myr based on a new generalized database, Geophys. J. Int., 131, 240-252, 1997.

Moore, G., C. Marone, I. S. E. Carmichael, and P. Renne, Basaltic volcanism and extension near the intersection of the Sierra Madre volcanic province and the Mexican Volcanic Belt, Geol. Soc. Am. Bull., 106, 383-394, 1994

Murillo-Muñeton, G. and R. Torres-Vargas, Mapa petrogenetico y radiometrico de la Republica Mexicana. Proyecto C-2010. Instituto Mexicano del Petroleo, Subdirección de tecnología de exploración, Internal Report, 256 pp., 1987.

Nieto Obregon, J., L. Delgado Argote, and P. E. Damon, Relaciones petrologicas y geocronologicas del magmatismo de la Sierra Madre Occidental y el Eje Neovolcanico en Nayarit, Jalisco y Zacatecas, Asoc. Ing. Min. Met. Geol. Mex. Memoria XIV ${ }^{\circ}$ Conv. Nac., 327-361, 1981.

Nieto-Samaniego, A., L. Ferrari, S. Alaniz-Alvarez, G. Labarthe-Hernandez, and J. Rosas-Elguera, Variation of Cenozoic extension and volcanism across the southern Sierra Madre Occidental volcanic province, Mexico. Geol. Soc. Am. Bull., 111, 347-363, 1999.

Nishitani, T. and M. Kono, Effects of low-temperature oxidation on the remanence properties of titanomagnetites, J. Geomag. Geoelectr., 41, 19-38, 1989.

Nixon, G. T., A. Demant, R. L. Amstrong, and J. E. Harakal, K-Ar and geologic data bearing on the age and evolution of the Trans-Mexican Volcanic Belt, Geofísica Internacional, 26, 109-158, 1987.

Özdemir, Ö., Inversion of titanomaghemites, Phys. Earth Planet. Inter., 65, $125-136,1987$.

Özdemir, Ö. and D. J. Dunlop, Chemico-viscous remanent magnetization in Fe3O4-gFe2O3 system, Science, 243, 1043-1047, 1989.

Pasquarè, G., V. H. Garduño, A. Tibaldi, and M. Ferrari, Stress pattern evolution in the central sector of the Mexican Volcanic Belt, Tectonophys. 146, 352-364, 1988.

Pasquarè, G., L. Ferrari, V. H. Garduño, A. Tibaldi, and L. Vezzoli, Geology of the central sector of Mexican Volcanic Belt, States of Guanajuato and Michoacan, 22 pp., Geol. Soc. Am., Map and Chart series, MCH 072, 1991.

Readman, P. W. and W. O'Reilly, Magnetic properties of oxidized (cationdeficient) titanomagnetites, (Fe,Ti,?)O4. J. Geomag. Geoelectr., 24, 6990, 1972.

Righter, K., I. S. E. Carmichael, and T. Becker, Pliocene-Quaternary volcanism and faulting at the intersection of the Gulf of California and the Mexican Volcanic Belt, Geol. Soc. Am. Bull., 107, 612-626, 1995.

Rosas-Elguera, J. and J. Urrutia-Fucugauchi, Tectonic control on the volcano-sedimentary sequence of the Chapala graben, western Mexico, International Geology Review, 40, 350-362, 1998.

Rosas-Elguera, J., J. Urrutia-Fucugauchi, and R. Maciel-Flores, Geologia del extremo oriental del Graben de Chapala; breve discusion sobre su edad: zonas geotermicas Ixtlan de Los Hervores-Los Negritos, Mexico. Geotermia, Rev. Mexicana Geoenergia, 5, 3-18, 1989.

Steiger, R. H. and E. Jäger, Subcommission on geochronology: convention on the use of decay constants in geo- and cosmochronology, Earth Planet Sci. Lett., 36, 359-362, 1977.

Suter, M., M. Carrillo, M. Lopez, and E. Farrar, The Aljibes half-graben, active extension at the boundary between the trans-Mexican Volcanic Belt 
and the southern Basin and Range, Geol. Soc. Am. Bull., 107, 627-641, 1995.

Tauxe, L., T. A. T. Mullender, and T. Pick, Pot-bellies, wasp-waists and superparamagnetism in magnetic hysteresis, J. Geophys. Res., 95, 12,33712,350, 1996.

Urrutia-Fucugauchi, J., Estudio paleomagnetico de rocas igneas del noreste del estado de Jalisco, Mexico, Ms Sc Thesis, Universidad Nacional Autonoma de Mexico, 292 pp., 1976.

Urrutia-Fucugauchi, J., Paleomagnetism of the Miocene Jantetelco granodiorites and Tepexco volcanic group and inferences of crustal block rotations in central Mexico, Tectonophys., 76, 149-168, 1981.

Urrutia-Fucugauchi, J. and H. Böhnel, Tectonics along the Trans-Mexican volcanic belt according to paleomagnetic data, Phys. Earth Planet. Int., 52, 320-329, 1988.

Urrutia-Fucugauchi, J. and J. Rosas-Elguera, Paleomagnetic study of the eastern sector of Chapala Lake and implications for the tectonics of westcentral Mexico, Tectonophys., 239, 61-71, 1994.

Verma, S. P., M. Lopez-Martinez, and D. J. Terrell, Geochemistry of Tertiary igneous rocks from Arandas-Atotonilco area, northeast Jalisco, Mexico, Geofísica Internacional, 24, 31-45, 1987.

Watkins, N. D., B. M. Gunn, A. K. Baksi, D. York, and J. Ade-Hall, Paleomagnetism, geochemistry and potassium-argon ages of the Rio Grande de Santiago volcanics, Central Mexico, Geol. Soc. Am. Bull., 82, 19551968, 1971.

L. M. Alva-Valdivia (e-mail: lalva@igeofcu.unam.mx), A Goguitchaichvili, L. Ferrari, J. Rosas-Elguera, J. Urrutia-Fucugauchi, and J. J. Zamorano-Orozco 